\title{
Evaluation of the Effect of Hydroethanolic Root Extract and Solvent Fractions of Cyphostemma adenocaule (Steud. ex A. Rich) Descoings ex Wild \& Drummond on Cell-Mediated Immune Response and Blood Cell Count in Mice
}

\author{
Dehnnet Abebe $\mathbb{D}^{\mathbb{D}},{ }^{1}$ Gomathi Periasamy $\mathbb{I D}^{2},{ }^{2}$ Aman Karim $\mathbb{D}^{2},{ }^{2}$ and Helen Bitew $\mathbb{D}^{2}$ \\ ${ }^{1}$ Debre Markos University, Debre Markos, Ethiopia \\ ${ }^{2}$ Mekelle University, Mekelle, Ethiopia \\ Correspondence should be addressed to Dehnnet Abebe; dehnnetabebe@gmail.com
}

Received 30 May 2020; Revised 8 December 2020; Accepted 27 January 2021; Published 10 February 2021

Academic Editor: Célia Cabral

Copyright (c) 2021 Dehnnet Abebe et al. This is an open access article distributed under the Creative Commons Attribution License, which permits unrestricted use, distribution, and reproduction in any medium, provided the original work is properly cited.

\begin{abstract}
Introduction. Cyphostemma adenocaule (Steud. ex A. Rich) Descoings ex wild \& Drummond (Vitaceae) has been used in traditional medicine for the management of various immunological and hematological disorders in different areas of Ethiopia and the rest of the world. In Ethiopia, the plant is used for the management of enlarged spleen, rabies virus, helminthic infection, snake bite, and various types of tumors. Objective. To evaluate the effect of hydroethanolic root extract and solvent fractions of Cyphostemma adenocaule on cell-mediated immunity (delayed-type hypersensitivity), organ index (spleen and liver), and blood cell count in Swiss albino mice. Materials and Methods. Acute oral toxicity test was conducted using nulliparous and nonpregnant Swiss albino mice following OECD 425 limit test method. Delayed-type hypersensitivity model was used to evaluate the effect on cell-mediated immunity. The experimental animals were divided into twelve groups which were sensitized and challenged with sheep red blood cells on day 0 and day 7 , respectively. Levamisole $50 \mathrm{mg} / \mathrm{kg}$ was used as stimulant control, whereas cyclophosphamide $30 \mathrm{mg} / \mathrm{kg}$ was used as suppressant control. Hydroethanolic root extract $(100 \mathrm{mg} / \mathrm{kg}, 200 \mathrm{mg} / \mathrm{kg}$, and $400 \mathrm{mg} / \mathrm{kg}$ ), aqueous fraction $(100 \mathrm{mg} / \mathrm{kg}, 200 \mathrm{mg} / \mathrm{kg}$, and $400 \mathrm{mg} / \mathrm{kg})$, and $n$-butanol fraction $(100 \mathrm{mg} / \mathrm{kg}, 200 \mathrm{mg} / \mathrm{kg}$, and $400 \mathrm{mg} / \mathrm{kg})$ were administered for seven days. The paw volume was measured using a digital plethysmometer before challenge and 24 hours after challenge. Blood was collected, and organs (spleen and liver) were isolated from each challenged mouse to determine blood cell count and organ index, respectively. Results. No mortality and noticeable behavioral changes were observed among all mice receiving hydroethanolic root extract and solvent fractions at a dose of $2000 \mathrm{mg} / \mathrm{kg}$. Hydroethanolic root extract and solvent fractions of Cyphostemma adenocaule showed enhancement of delayed-type hypersensitivity, organ index, and blood cell count. Hydroethanolic root extract at a dose of $400 \mathrm{mg} / \mathrm{kg}$ showed the highest and statistically significant stimulation of delayed-type hypersensitivity $(0.123 \pm 0.010)$ and blood cell count compared to the vehicle. Conclusion. Hydroethanolic root extract and solvent fractions of Cyphostemma adenocaule showed a stimulatory effect on cell-mediated immunity and hematopoiesis.
\end{abstract}

\section{Introduction}

Alteration of the structure and functions of the immune system leads to suppression or stimulation of the immune response. The immune system which can be innate or adaptive is responsible for the protection of the body from infection and other immunological disorders [1].
The whole plant and phytoconstituents of many plants of various taxonomic classes exhibited immunomodulatory properties to an antigenic material that gets access to the body of living cells. Cyphostemma adenocaule (Vitaceae family) is an herbaceous climber widely distributed in Ethiopia [2]. In traditional medicine, C. adenocaule has been used for the treatment of various illnesses such as malaria, 
helminthic infection, cancer, tumors, snake bite, rabies, and anthrax [3-6]. Earlier scientific studies showed that C. adenocaule has in vitro antiplasmodial [7], antioxidant [8], and deworming [9] effects. The anti-infective, antitoxin, and antitumor activity of this plant might be due to its effect on the cellular immune system and accessory cell types. Therefore, this study aimed to demonstrate the effect of hydroethanolic root extract and solvent fractions of C. adenocaule on cell-mediated immunity, blood cell count, and organ index in Swiss albino mice.

\section{Materials and Methods}

\subsection{Materials}

2.1.1. Plant, Chemicals, Reagents, and Standard Drugs. The roots of $C$. adenocaule were collected from the Angacha riverside of Teda woreda, North Gondar, Ethiopia. The chemicals and reagents used for the study were purchased from local suppliers in Mekelle, Ethiopia. Normal saline (Addis Pharmaceutical Factory/APF, Addis Ababa, Ethiopia), $n$-hexane (Loba Chemie. Pvt. Ltd, India), ethanol (Fine Chemical general trading, Addis Ababa, Ethiopia), distilled water (Amshaj Manufacturing plc., Addis Ababa, Ethiopia), $n$-butanol (CARLO ERBA Reagents SAS, France), gum acacia (Shreeji Pharma International, India), levamisole (Ningbo Shuangwei Pharm. Co. Ltd., China), and cyclophosphamide (Cadila health care Ltd., India) were used. All the chemicals, reagents, and standard drugs were of laboratory/analytical grade. Sheep blood and Alsever's solution were also used during the study.

2.1.2. Experimental Animal. Female nulliparous and nonpregnant Swiss albino mice aged 8-12 weeks were used for the acute toxicity study, whereas for the main study, healthy, Swiss albino mice of either sex (weight $25 \pm 5 \mathrm{~g}$, and 6-8 weeks of age) obtained from the animal house of the School of Pharmacy, College of Health Sciences, Mekelle University, were used. The mice were housed in a laboratory of $12 / 12 \mathrm{hr}$ light/dark cycle with the provision of a commercial pellet diet and water ad libitum. Before beginning the experiment, the animals were acclimatized to the laboratory condition for a week.

\subsection{Methods}

2.2.1. Collection and Authentication of the Plant. The plant sample was collected from Angacha riverside and authenticated by Mr. Getnet Chekol (Botanist, University of Gondar, Ethiopia), and a sample specimen (voucher DA01/2018) was deposited in the herbarium of the university. The roots of the plant were collected, washed with tap water, and shade-dried.

2.2.2. Extraction and Fractionation. Shade-dried roots were powdered with an electric grinder of which one kilogram of the powder was macerated with $70 \%(\mathrm{v} / \mathrm{v})$ ethanol $(1: 5$ ratios) for 72 hours which was then filtered with a muslin cloth and Whatman filter paper No. 1 to remove any insoluble matter.

The marc was remacerated twice with the same solvent for 72 hours [8]. All the filtrates were dried in an oven at $37^{\circ} \mathrm{C}$. 60 gram of the dried extract was dispersed in water (1: 5 ratios) and fractionated by successively treating the dispersed medium with $n$-hexane and $n$-butanol in triplicates. The three fractions (aqueous, $n$-butanol, and $n$-hexane) were dried in an oven at $37^{\circ} \mathrm{C}$.

2.2.3. Sheep Red Blood Cell (SRBC) Preparation and Standardization. Fresh blood was collected from the external jugular vein of sheep and mixed with freshly prepared Alsever's solution ( $2 \%$ dextrose, $0.8 \%$ sodium citrate, $0.055 \%$ citric acid, and $0.42 \%$ sodium chloride) in $1: 1$ proportion.

The collected blood was centrifuged at $2500 \mathrm{rpm}$ for 10 min to separate the plasma and washed thrice in pyrogenfree normal saline $(0.9 \% \mathrm{w} / \mathrm{v})$ with subsequent centrifugation. The SRBCs were suspended in normal saline, and their count was adjusted to a concentration of $1 \times 10^{8}$ cells in $1 \mathrm{~mL}$ of sheep blood which was used as T-lymphocyte-dependent antigens for immunization and challenge of the mice $[10,11]$.

2.2.4. Acute Oral Toxicity Testing. Female nulliparous and nonpregnant Swiss albino mice were used for the study for each extract and solvent fraction. The test was performed following the Organization for Economic Cooperation and Development (OECD) guideline 425 using limit test method [12].

2.2.5. Animal Grouping and Dosing. SRBC-sensitized and challenged mice were randomly grouped into twelve groups of six mice each that received the respective dose of vehicle/ standard drug/extract/solvent fractions as shown in Table 1.

2.2.6. Delayed-Type Hypersensitivity (DTH). All groups of mice were immunized with $0.1 \mathrm{~mL}$ of SRBC (i.p) on day 0 and received an oral dose of respective treatment for 7 days. On the 7th day, one hour after administration of the respective dose, the paw volume of the left leg of each mouse was measured with a digital plethysmometer and challenged with a subcutaneous injection of $0.05 \mathrm{~mL}$ of SRBC into the hind footpad of the same leg. The volume of the challenged paw was measured 24 hours after the challenge. The difference in paw volume between the pre- and postchallenge was taken as a measure of DTH response, and the percentage change in paw volume was determined using the following equation $[13,14]$ :

$$
\% \text { Swlling }=\frac{(\mathrm{PV} \text { treatment }-\mathrm{PV} \text { vehicle })}{\mathrm{PV} \text { treatment }} * 100,
$$

PV: paw volume of mice receiving each treatment dose and vehicle.

2.2.7. Effect on Blood Cell Count and Organ Index. At the end of the treatment period of the DTH model, blood was withdrawn from the retro-orbital plexus of all groups of mice 
TABLE 1: Animal grouping and dosing.

\begin{tabular}{lr}
\hline Treatment group dose & Dose \\
\hline Normal control (vehicle (2\% gum acacia)) & $10 \mathrm{ml} / \mathrm{kg}$ \\
Cyclophosphamide (CP) control & $30 \mathrm{mg} / \mathrm{kg}$ \\
Levamisole control & $50 \mathrm{mg} / \mathrm{kg}$ \\
Hydroethanolic extract (CEE 100) & $100 \mathrm{mg} / \mathrm{kg}$ \\
Hydroethanolic extract (CEE 200) & $200 \mathrm{mg} / \mathrm{kg}$ \\
Hydroethanolic extract (CEE 400) & $400 \mathrm{mg} / \mathrm{kg}$ \\
Aqueous fraction (AF 100) & $100 \mathrm{mg} / \mathrm{kg}$ \\
Aqueous fraction (AF 200) & $200 \mathrm{mg} / \mathrm{kg}$ \\
Aqueous fraction (AF 400) & $400 \mathrm{mg} / \mathrm{kg}$ \\
$n$-Butanol fraction (BF 100) & $100 \mathrm{mg} / \mathrm{kg}$ \\
$n$-Butanol fraction (BF 200) & $200 \mathrm{mg} / \mathrm{kg}$ \\
$n$-Butanol fraction (BF 400) & $400 \mathrm{mg} / \mathrm{kg}$ \\
\hline
\end{tabular}

TABLE 2: The effect of controls, hydroethanolic root extract, and solvent fractions of Cyphostemma adenocaule on delayed-type hypersensitivity response and organ index.

\begin{tabular}{|c|c|c|c|c|c|}
\hline \multirow{2}{*}{ Treatment group } & \multirow{2}{*}{ Dose $(\mathrm{mg} / \mathrm{kg})$} & \multirow{2}{*}{ DTH $($ mean \pm SEM $)$} & \multirow{2}{*}{ Swelling (\%) } & \multicolumn{2}{|c|}{ Organ index $(\mathrm{mg} / \mathrm{g})$} \\
\hline & & & & Spleen & Liver \\
\hline$\overline{\mathrm{VH}}$ & - & $0.065 \pm 0.013$ & - & $4.594 \pm 0.123$ & $44.35 \pm 0.862$ \\
\hline LEV & 50 & $0.112 \pm 0.013^{\mathrm{cl}}$ & $\uparrow 41.96$ & $5.016 \pm 0.200^{\mathrm{c} 3}$ & $52.000 \pm 1.718^{\mathrm{a} 3 \mathrm{c} 3}$ \\
\hline \multirow[t]{2}{*}{ CYP } & 30 & $0.055 \pm 0.015$ & $\downarrow 18.18$ & $3.859 \pm 0.094$ & $39.981 \pm 0.564$ \\
\hline & 100 & $0.091 \pm 0.003$ & $\uparrow 28.57$ & $4.778 \pm 0.107^{\mathrm{c} 3}$ & $48.000 \pm 0.807^{\mathrm{c} 3}$ \\
\hline \multirow[t]{3}{*}{ HEE } & 200 & $0.113 \pm 0.011$ & $\uparrow 42.48$ & $5.094 \pm 0.114^{\mathrm{c} 3}$ & $48.330 \pm 1.100^{\mathrm{c} 3}$ \\
\hline & 400 & $0.123 \pm 0.010^{\mathrm{cl}}$ & $\uparrow 47.15$ & $5.359 \pm 0.174^{\mathrm{a} 2 \mathrm{c} 3 \mathrm{~g} 1}$ & $52.381 \pm 1.720^{\mathrm{a} 3 \mathrm{c} 3}$ \\
\hline & 100 & $0.081 \pm 0.007$ & $\uparrow 19.75$ & $4.716 \pm 0.128^{\mathrm{c} 3}$ & $47.592 \pm 1.122^{\mathrm{c} 3}$ \\
\hline \multirow[t]{3}{*}{$\mathrm{AF}$} & 200 & $0.092 \pm 0.005$ & $\uparrow 29.35$ & $4.861 \pm 0.095^{\mathrm{c} 3}$ & $47.800 \pm 1.098^{\mathrm{c} 3}$ \\
\hline & 400 & $0.109 \pm 0.011^{\mathrm{alc} 3}$ & $\uparrow 40.37$ & $4.967 \pm 0.131^{\mathrm{c} 3}$ & $47.912 \pm 0.940^{\mathrm{c} 3}$ \\
\hline & 100 & $0.086 \pm 0.013$ & $\uparrow 24.42$ & $4.768 \pm 099^{\mathrm{c} 3}$ & $47.660 \pm 1.202^{\mathrm{c} 3}$ \\
\hline \multirow[t]{2}{*}{$\mathrm{BF}$} & 200 & $0.100 \pm 0.007$ & $\uparrow 35.00$ & $4.839 \pm 0.095^{\mathrm{c} 3}$ & $48.040 \pm 1.006^{\mathrm{c} 3}$ \\
\hline & 400 & $0.113 \pm 0.012^{\mathrm{c} 1}$ & $\uparrow 42.48$ & $5.346 \pm 0.164^{\mathrm{a} 2 \mathrm{c} 3}$ & $51.815 \pm 1.131^{\mathrm{a} 3 \mathrm{c} 3}$ \\
\hline
\end{tabular}

Values are expressed as mean \pm SEM, $n=6$. Abbreviations: DTH=delayed-type hypersensitivity, $\mathrm{VH}=$ vehicle $(2 \%$ gum acacia), LEV=levamisole, $\mathrm{CYP}=$ cyclophosphamide, $\mathrm{HEE}=$ hydroethanolic extract, $\mathrm{AF}=$ aqueous fraction, $\mathrm{BF}=n$-butanol fraction, $\uparrow=$ increase in paw volume, $\downarrow=$ decrease in paw volume, $\mathrm{a}=$ compared to vehicle, $\mathrm{c}=$ compared to cyclophosphamide, $\mathrm{g}=$ compared to $100 \mathrm{mg} / \mathrm{kg}$ aqueous fraction, $1=p<0.05,2=p<0.01$, and $3=p<0.001$.

to determine blood cells. Following blood withdrawal, the spleen and liver were isolated and weighed immediately to determine their relative index using the following equation $[11,15]$ :

$$
\operatorname{organ} \text { index }(\mathrm{mg} / \mathrm{g})=\frac{\text { weight of } \operatorname{organ}(\mathrm{mg})}{\text { weight of mice }(\mathrm{g})} \text {. }
$$

2.3. Statistical Analysis. The data from each group were analyzed using SPSS version 20 software. Results were presented as mean \pm SEM (standard error of mean). The difference of treatment group means from each other and the control mean values was determined by using one-way ANOVA followed by Tukey post hoc multiple comparison test, and $p$ values $<0.05$ were considered significant.

2.4. Ethical Consideration. Mice were handled, used, and sacrificed following the procedures approved by the Health Research Ethics Review Committee (HRERC) of Mekelle
University, College of Health Sciences, with provided ERC code of $1548 / 2018$.

\section{Results and Discussion}

3.1. Acute Oral Toxicity Test. The acute toxicity study showed that no mortality and noticeable behavioral change were observed in all mice that received $2000 \mathrm{mg} / \mathrm{kg}$ of the hydroethanolic root extract and solvent fractions (aqueous and $n$-butanol fractions).

3.2. Delayed-Type Hypersensitivity Test. In DTH test, groups treated with levamisole, hydroethanolic root extract, and the solvent fraction of $C$. adenocaule showed a dose-dependent increase in DTH response compared to the vehicle (Table 2). This enhancement in DTH response indicated the stimulation of cell-mediated response to SRBC which could be due to the activation of the production of lymphocytes and accessory cell types which play the central role in DTH response. It might also be due to the production of memory $\mathrm{T}$ lymphocytes during sensitization with SRBC that are 


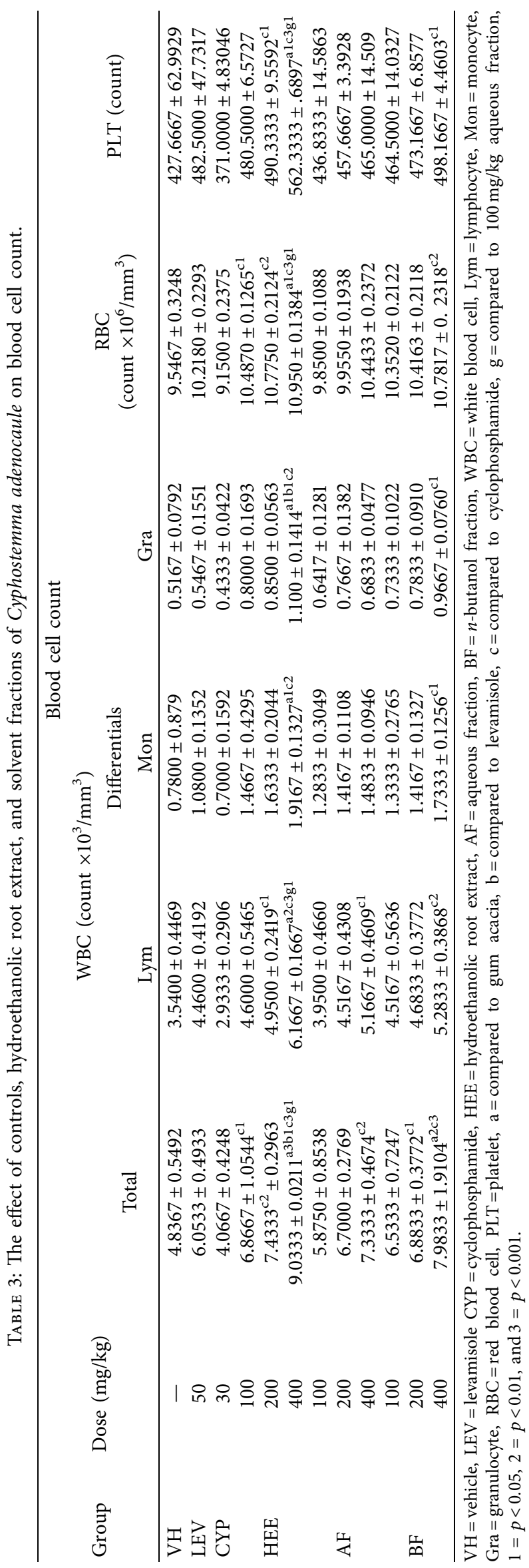


activated to lymphoblasts upon challenging [16]. Hydroethanolic root extract at a dose of $400 \mathrm{mg} / \mathrm{kg}$ revealed the highest $(0.123 \pm 0.010)$ and statistically significant $(p<0.05)$ DTH response enhancing the paw volume by $47.15 \%$ compared to the vehicle. Although the hydroethanolic root extracts at all doses revealed the highest DTH response compared to the solvent fractions of comparable dose, no statically significant difference $(p>0.05)$ was observed. The increased DTH response might be attributable to the presence of tannins, flavonoids, saponins, alkaloids, and carbohydrates [17-19].

3.3. Organ Index. The hydroethanolic root extract and solvent fractions of $C$. adenocaule induced an increase in organ index compared to the vehicle (Table 2) which might be attributable to the stimulatory effect of treatment on the growth and development of organs. Hydroethanolic root extract at a dose of $400 \mathrm{mg} / \mathrm{kg}$ induced the highest spleen index $(5.359 \pm 0.174)$. The increase in organ index might also be due to the stimulatory effect of treatment on proliferation and differentiation of bone marrow stem cells that migrate to and settle within the organ for interaction with the incoming antigen, thereby increasing the mass of the organ [20].

3.4. Blood Cell Count. In the present study, Hydroethanolic root extract and solvent fractions of $C$. adenocaule increased the blood cell count compared to the vehicle (Table 3) which might be due to stimulation of the proliferation and differentiation of hematopoietic stem cells (HSCs) in the bone marrow giving rise to functioning blood cells [21]. It might also be due to the reported antioxidant property (IC50 of $38.42 \mu \mathrm{g} / \mathrm{mL}$ ) of the study plant that prevents cells from oxidative damage [8]. Hydroethanolic root extract revealed the highest blood cell count compared to solvent fractions of comparable dose which might be accredited to the presence of a larger quantity of antioxidant phytoconstituents at higher concentrations compared to their existence in solvent fractions of comparable dose, thereby enhancing hematopoiesis through synergistic effect [22]. This finding agreed with the finding of Ojogbane and his coworkers who demonstrated the enhancement of WBC count with the administration of aqueous extract of C. glaucophilla leaves [23].

\section{Conclusion}

From this study, it can be concluded that hydroethanolic root extract and solvent fractions of $C$. adenocaule had stimulatory properties on the cell-mediated immune response.

\section{Data Availability}

The data generated and/analyzed during the study will be available from the corresponding author upon reasonable request.

\section{Conflicts of Interest}

The authors declare that there are no conflicts of interest.

\section{Acknowledgments}

The authors thank the financial support provided by Mekelle University and Debre Markos University. They also thank Ayer Comprehensive Specialized Hospital, Mekelle, Ethiopia, and Tigray Regional Health Research Institute for provision of sheep blood for the study. They are also grateful to Mr. Getinet Chekol (Botanist, University of Gondar) and Mr. Abyot Endale (Associate professor of Pharmacognosy, University of Gondar) for identifying the plant and provision guidance during plant selection, respectively.

\section{References}

[1] P. Venkatalakshmi, V. Vadivel, and P. Brindha, "Role of phytochemicals as immunomodulatory agents: a review," International Journal of Green Pharmacy, vol. 10, no. 1, pp. 1-18, 2016.

[2] G. J. . Grubben and O. Denton, "Cyphostemma adenocaule (Steud. ex. A. rich) wild \& R. B. Drumm," PROTA Vegetables, vol. 2, no. 2, p. 473, 1966.

[3] S. Araya, B. Abera, and G. Mirutse, "Study of plants traditionally used in public and animal health management in Seharti Samre district, southern Tigray, Ethiopia," Journal of Ethnobiology and Ethnomedicine, vol. 11, no. 22, pp. 1-25, 2015.

[4] Z. Birhanu, A. Endale, and Z. Shewamene, "An ethnomedicinal investigation of plants used by traditional healers of Gondar town, north- western Ethiopia," Journal of Medicinal Plants Studies, vol. 3, no. 2, pp. 36-43, 2015.

[5] P. Nalumansi, M. Kamatenesi-Mugisha, and A. Godwin, "Medicinal plants used in paediatric health care in Namungalwe sub county, Iganga district, Uganda," Nova Journal of Medical and Biological Sciences, vol. 2, no. 3, pp. 1-14, 2014.

[6] D. O. Ochwang, C. Kimwele, J. Oduma, P. Gathumbi, J. Mbaria, and S. Kiama, "Medicinal plants used in treatment and management of cancer in Kakamega county, Kenya," Journal of Ethnopharmacology, vol. 151, no. 3, pp. 1040-1055, 2014.

[7] J. R. Chouna, F. Nardella, B. Lenta, C. Vonthron-Senecheau, P. Nkeng-Efouet-Alango, and N. Sewald, "Ceanothane-type triterpenoids from Cyphostemma adenocaule," Archives of Pharmacal Research, pp. 1-6, 2016.

[8] A. Feyisayo, A. Oluwafemi, and O. Oluokun, "Evaluation of antioxidant capacity and membrane stabilizing potential of stem and root of Cyphospenna adenocaulis (Steud)," African Journal of Biotechnology, vol. 14, no. 21, pp. 1820-1827, 2015.

[9] O. M. Bello, S. M. Jagaba, O. E. Bello et al., "Phytochemistry, pharmacology and perceived health uses of non-cultivated vegetable Cyphostemma adenocaule (Steud. ex A. Rich.) Desc. ex Wild and R. B. Drumm: a review," Scientific African, vol. 2, Article ID e00053, 2019.

[10] L. Ahirwal, S. Singh, M. Dubey, V. Bharti, A. Mehta, and S. Shukla, "In vivo immunomodulatory effects of the methanolic leaf extract of Gymnema sylvestre in Swiss albino mice," Archives of Biological Sciences, vol. 67, no. 2, pp. 561-570, 2015.

[11] P. Shrestha and M. Handral, "Evaluation of immunomodulatory activity of extract from rind of Nephelium lappaceum 
fruit," International Journal of Pharmacy and Pharmaceutical Sciences, vol. 9, no. 1, pp. 38-43, 2017.

[12] OECD, OECD Guidelines for the Testing of Chemicals, Acute Oral Toxicity-Up-and-Down-Procedure (UDP), OECD, Paris, France, 2008.

[13] F. R. Carrasco, G. Schmidt, A. L. Romero et al., "Immunomodulatory activity of Zingiber officinale Roscoe, Salvia officinalis L. and Syzygium aromaticum L. essential oils: evidence for humor- and cell- mediated responses," Journal of Pharmacy and Pharmacology, vol. 61, pp. 961-967, 2009.

[14] D. G. Kanjwani, T. Marathe, T. Marathe, and S. Sathaye, "Evaluation of immunomodulatory activity of methanolic extract of Piper betel," Scandinavian Journal of Immunology, vol. 67, no. 6, pp. 589-593, 2008.

[15] A. Tripathi, V. Chitra, N. Sheikh, and D. Mohale, "Immunomodulatory activity of the methanol extract of Amorphophallus campanulatus (Araceae) tuber," Tropical Journal of Pharmaceutical Research, vol. 9, no. 5, pp. 451-454, 2010.

[16] J. Owen, J. Punt, S. Stranford, and P. Jones, Kuby Immunology, Susan Winslow, New York, NY, USA, 7th edition, 2013.

[17] C. Ojiako, E. Okoye, A. Oli, C. Ike, C. Esimone, and A. Attama, "Preliminary studies on the formulation of immune stimulating complexes using saponin from Carica papaya leaves," Heliyon, vol. 5, no. 6, pp. 1-7, 2019.

[18] A. Pathak, N. Dutta, A. Pattanaik, K. Sharma, P. Banerjee, and T. Goswami, "The effect of condensed tannins supplementation through Ficus infectoria and Psidium guajava leaf meal mixture on erythrocytic antioxidant status, immune response and gastrointestinal nematodes in lambs (Ovis aries)," Veterinarski Arhiv, vol. 87, no. 2, pp. 139-156, 2017.

[19] A. G. Vigila and X. Baskaran, "Immunomodulatory effect of coconut protein on cyclophosphamide induced immune suppressed swiss albino mice," Ethnobotanical Leaflets, vol. 12, pp. 1206-1212, 2008.

[20] S. Hartati, T. Untari, I. Fitriyani, and B. Sutrisno, "Evaluation of immunomodulatory activity of the herbals formula Viranur, turmeric (Curcuma heyneana val.) and Phyllanthus (Phyllanthus niruri L.) in layer chicken vaccinated with Avian influenza," Journal of Agricultural Science and Technology, vol. 5, no. 8, pp. 695-702, 2015.

[21] K. Murphy and C. Weaver, Janeways Immunology, Garland Science, New York, NY, USA, 8th edition, 2015.

[22] E. M. Williamson, "Synergy and other interactions in phytomedicines," Phytomedicine, vol. 8, no. 5, pp. 401-409, 2001.

[23] E. Ojogbane, O. James, and O. F. C. Nwodo, "Effects of aqueous extract of Cyphostemma glaucophilla leaves on some specific and non-specific immune responses in Albino rats," British Journal of Pharmacology and Toxicology, vol. 4, no. 4, pp. 142-146, 2013. 